\title{
Benefits of insect colours: a review from social insect studies
}

\author{
Oluwatobi Badejo $^{1}\left[\right.$ O Oksana Skaldina ${ }^{1}\left[\right.$ ] $\cdot$ Aleksei Gilev $^{2,3} \cdot$ Jouni Sorvari $^{1,4}(\mathbb{0}$
}

Received: 29 January 2020 / Accepted: 19 August 2020 / Published online: 2 September 2020

(c) The Author(s) 2020

\begin{abstract}
Insect colours assist in body protection, signalling, and physiological adaptations. Colours also convey multiple channels of information. These channels are valuable for species identification, distinguishing individual quality, and revealing ecological or evolutionary aspects of animals' life. During recent years, the emerging interest in colour research has been raised in social hymenopterans such as ants, wasps, and bees. These insects provide important ecosystem services and many of those are model research organisms. Here we review benefits that various colour types give to social insects, summarize practical applications, and highlight further directions. Ants might use colours principally for camouflage, however the evolutionary function of colour in ants needs more attention; in case of melanin colouration there is evidence for its interrelation with thermoregulation and pathogen resistance. Colours in wasps and bees have confirmed linkages to thermoregulation, which is increasingly important in face of global climate change. Besides wasps use colours for various types of signalling. Colour variations of well chemically defended social insects are the mimetic model for unprotected organisms. Despite recent progress in molecular identification of species, colour variations are still widely in use for species identification. Therefore, further studies on variability is encouraged. Being closely interconnected with physiological and biochemical processes, insect colouration is a great source for finding new ecological indicators and biomarkers. Due to novel digital imaging techniques, software, and artificial intelligence there are emerging possibilities for new advances in this topic. Further colour research in social insects should consider specific features of sociality.
\end{abstract}

Keywords Aposematism $\cdot$ Camouflage $\cdot$ Colouration $\cdot$ Thermal melanism $\cdot$ Hymenoptera

\section{Introduction}

Animals use colours for diverse purposes such as body protection, signalling, and physiological adaptations (Cott 1940; Caro and Notes 2005; Cuthill et al. 2017). Colour patterns vary in shapes, luminance, tints, or polarisation and convey multiple channels of information, essential for understanding ecological and evolutionary processes, occurring in nature (Endler and Mappes 2017). Therefore, investigations of colour patterns lead to important advances in science, technology, and design (Caro et al. 2017; Cuthill et al. 2017; Schroeder et al. 2018).

Communicated by Roland A. Brandl.

Oluwatobi Badejo and Oksana Skaldina equally contributed to the manuscript writing.

Oksana Skaldina

oksana.skaldina@uef.fi

Extended author information available on the last page of the article
Insects are the largest class of invertebrates. They are crucial for maintaining ecosystem functions and provide important ecosystem services vital to humans (Folgarait 1998; Noriega et al. 2018). Higher insect diversity favours higher functional diversity in the ecosystems, maintaining balance and sustainability. Many important ecosystem service providers (pollinators, predators, scavengers, seed dispersers) belong to hymenopteran social insects such as ants, wasps, and bees. During recent years, the increasing interest in colour research has substantially improved our understanding of colour variation in animals and led to several practical applications, particularly in social insects. Here we aim to review the functions that various aspects of colouration serve in insects with a focus on social insects and we outline the applications of assessing the colour variation of this remarkable aspect of the global biodiversity. 


\section{Insect colouration: types and functions}

\section{Pigment and structural colouration in insects}

Most insects exhibit colours via absorption or reflection of sunlight using pigments, cuticular surface structures, or their combination (Chapman et al. 2013). Only some springtails, flies, and beetles possess luciferasesenzymes, which catalyze light-producing biochemical reactions, being capable of bioluminescence (Viviani 2002). Several classes of pigments are involved with insect colouration. Generally, melanins produce shades from black to reddish-brown, and pterins, ommochromes, and carotenoids contribute to red, orange, and yellow colours (Fuzeau-Braesch 1972). Furthermore, flavonoids, which are plant secondary metabolites, also create orange colours in insects (Lindstedt et al. 2010). Bile pigments or bilins result in greenish and bluish tints, violet, and golden colours often appear because of structural interference (Chapman et al. 2013) (Fig. 1). Interestingly, some insect taxa have specific pigments, like aphins, producing a variety of tints in aphids (Shamim et al. 2014) and papilochromes, resulting in yellow, orange, and red colours in butterflies (Stavenga et al. 2014). Despite all diversity, melanins and pterins are two prevalent classes of insects' pigments
(Fuzeau-Braesch 1972). Sclerotisation (hardening) and melanisation (darkening) of insect cuticle can act in conjunction, and the appearance of a colour often is the result of both processes (Andersen 2010).

Pigments are deposited in distinct places of the cuticle, which can be venation structures on the butterflies' wings (Shvanvich 1949) or beetle elytra (Kreslavskiy 1975). Often these places are related to inner structures, such as outgrowths of the cuticle or places of the muscle attachments. For the insect species such as Colorado potato beetle (Leptinotarsa decemlineata), firebug (Pyrrhocoris apterus), and several wasp species (Vespula sp.) it has been shown that pigmented cuticle patterns are related to muscle bundle topography (they are places, where muscles are attached to cuticle, and the cuticle surface possess melanin spots in those places where they are attached) (Prisniy 1980; Batluzkaya 2003). Thus, insect colours depend on both pigments and structures. These structures have a morphological basis as described above or can be photonic structures, capable of interfering with visible light scale and possessing layers of the relatively high and low reflective index (Vukusic and Sambles 2003). Some specific colour tints in insects, for example, transparent white, golden-bronze, iridescent blue, or violet have only a structural basis (Fuzeau-Braesch 1972).

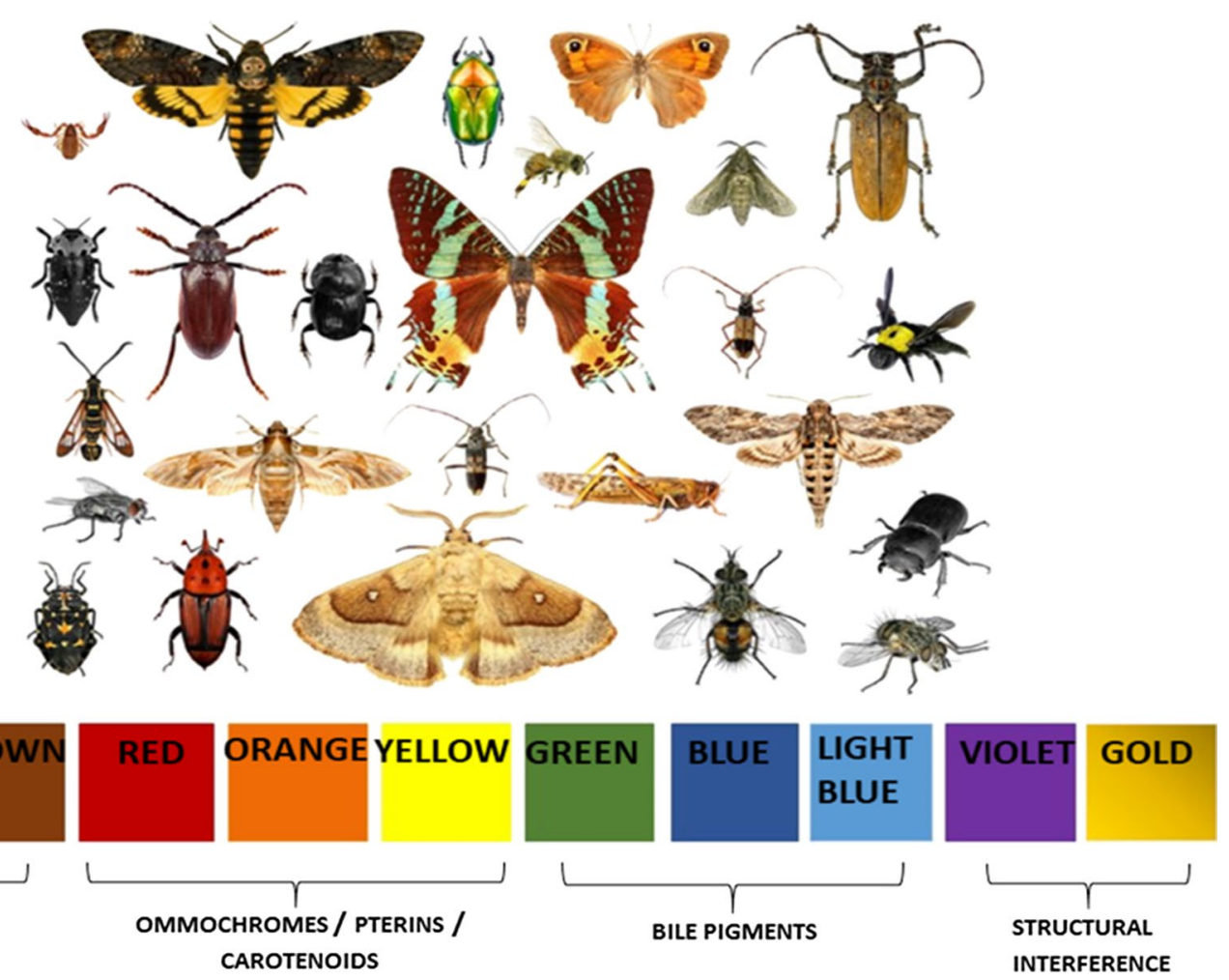

Fig. 1 Main classes of pigment- and structure-based colours in insects. Photo @ ProtasovAN 


\section{Functions of colour: body protection, signalling, physiology}

We consider the variety of colour functions in insects can be summarised as (1) body protection (physical, immunological); (2) signalling (camouflage, warning colouration, rival quality, mate choice), and (3) physiology (thermoregulation, UV-resistance, drought-resistance) (Fig. 2). In many cases, these functions are interacting, which highlights the multifunctional and integrative role of colouration. For example, camouflage and warning colouration can be referred to as both body protection and signaling (Figon and Casas 2018); or the thermoregulatory function of a colour can also possess a UV-radiation protective component. However, such a simplified classification clarifies the multifunctional and integrating role of colours in the insects' life (Fig. 3).

Colours are related to physical and immunological body protection. Darker cuticles are generally thicker, which prevent an insect body from the penetration of pathogens and parasites (Kalmus 1941; Armitage and Siva-Jothy 2005). Melanin pigments contribute both to insects' cuticle colouration and immunity (encapsulation response) (Gillespie

\section{COLOUR FUNCTIONS}

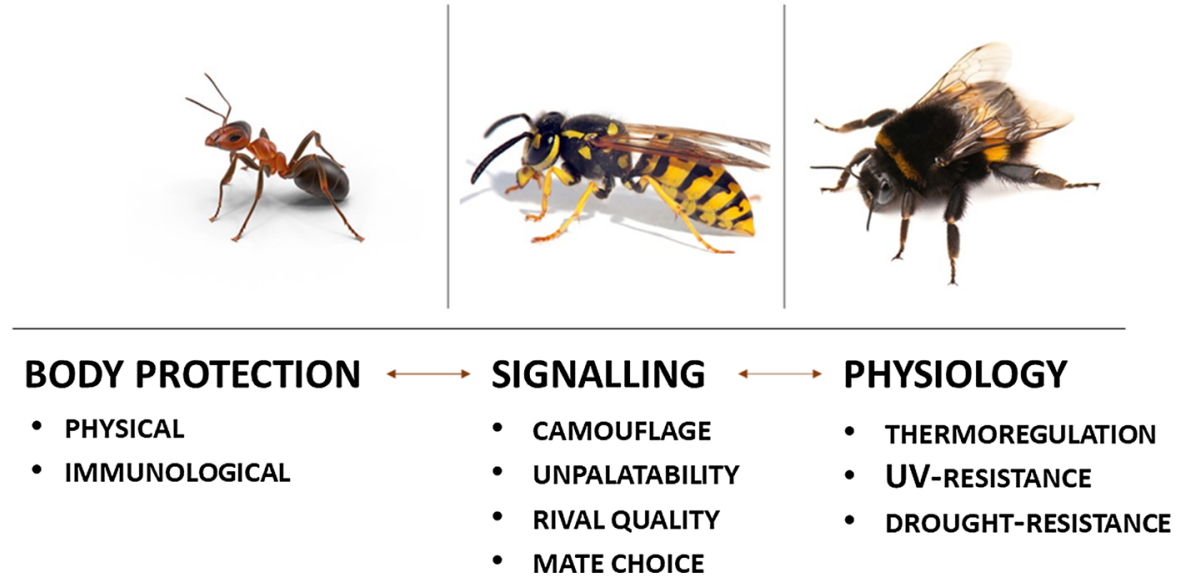

Fig. 2 Interconnections between colour functions in social insects (ants, wasps, and bees)

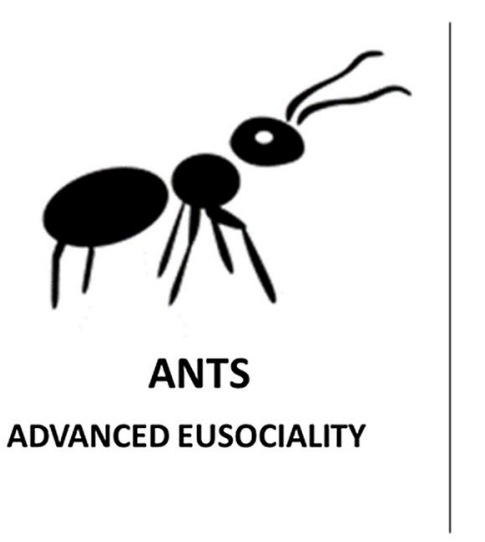

- ECOSYSTEM ENGINEERS

- PREDATORS

- POLLINATORS

-SCAVENGERS

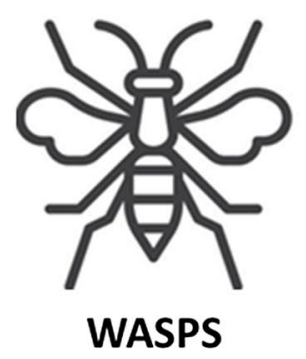

\section{ALL TRANSITIONS FROM \\ PRIMITIVE TO ADVANCED SOCIALITY}

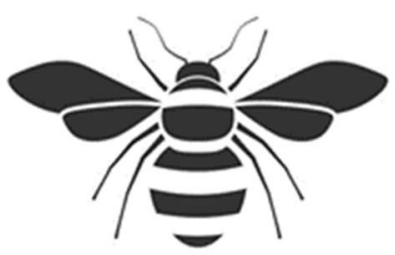

BEES

ALL TRANSITIONS FROM

PRIMITIVE TO ADVANCED SOCIALITY

-INVASIVE ALIEN SPECIES

-AGRICULTURAL PESTS

-VECTORS OF

MICROBIAL SPREAD

Fig. 3 Main groups of hymenopteran social insects (ants, bees, wasps), demonstrating different levels of sociality, and diverse aspects: (1) positive (marked with green) and (2) negative (marked with red) of their ecological role 
et al. 1997). Therefore, melanin-based colouration can be interconnected with immunological defence. For example, in Lepidoptera moth species Galleria mellonella, melanic morphs were more resistant to fungal infection compared to non-melanic ones (Dubovskiy et al. 2013). Similar results were reported for the mealworm beetle Tenebrio molitor (Evison et al. 2017) and the mormon cricket Anabrus simplex (Bailey 2011). Also, an immune challenge in freshly emerged mealworm beetles reduced melanin pigment in adulthood (Kangassalo et al. 2016); which indicates a clear relationship between immunity and melanisation.

Colours help insects to hide from or scare away predators. The main mechanisms for colour-concealment are crypsis, disruptive patterning, mimesis, countershading, and counter illumination (Stevens and Merilaita 2009). From the evolutionary point of view, insect camouflage is one of the two main adaptations that reduce predation risk (Théry and Gomez 2010). The other is a warning or aposematic colouration, which signals the unpalatability of an organism to predators. Lindström et al. (2004) listed the colours that combine with black on insect species to produce aposematism, namely: red, orange, yellow, and white.

If a colour pattern reflects the physiological condition of an individual, it is considered as a true quality signal (PerezRodriguez et al. 2017). Such quality signals are needed in the assessment of potential rivals or for the mate choice. Different insect species use colours for these purposes. For example, blue colours, distinguishing colouration of damselflies, require the development of bile pigments (Umbers 2013). In a damselfly Calopteryx maculata, blue colours were associated with fat, age, and social status of individuals (Fitzstephens and Getty 2000). Males of the blue-taled damselfly Ischnura elegans used colours as signals in mate choice; however, they preferred to mate with the females, possessing the colour morphs, which they have been experienced before (van Gossum et al. 2001). Many butterflies focus on wing colours and colour elements to select mate partners (Kemp and Rutowski 2011). In Colorado potato beetle, selective preference of different colour morphs for the mate choice has also been revealed (Grizenko et al. 1998). For several other beetle species, it was found that closely related species, sharing the same habitat, had noticeable colour differences associated with a quick search of a mating partner (Medvedev 1968; Kreslavskiy 1975).

Colour has beneficial physiological functions and is associated with thermoregulation, UV-light protection, and drought-resistance (True 2003; Clusella-Trullas et al. 2007; Rajpurohit et al. 2008; Roulin 2014; Pinkert and Zeuss 2018). The thermal melanism hypothesis states that individuals tend to be darker in colder environments and lighter in the warmer ones (Clusella-Trullas et al. 2007). This theory was confirmed with many examples from the insects' world. Thus, colour variations associated with temperature were revealed in beetles (Coleoptera) (Brakefield and Willmer 1985; Korsun 2000; Schweiger and Beierkuhlein 2015); butterflies (Lepidoptera) (Zeuss et al. 2014; Stelbrink et al. 2019), dragonflies (Odonata) (Zeuss et al. 2014; Pinkert et al. 2016), parasitic wasps (Hymenoptera) (Abe et al. 2013), crickets (Orthoptera) (Fedorka et al. 2013), and in the other insects. The other environmental driving force, shaping colour variations in insects, is UV-light protection. UV-protection hypothesis states that darker individuals are better protected from insolation, and it possesses several confirming examples (True et al. 2003). The interrelation between drought-resistance and colouration in insects is also conceptualized in the melanism-desiccation hypothesis. It states that the increased melanisation favors decreasing cuticle permeability, and therefore darker individuals are better adapted to drier environments (Rajpurohit et al. 2016; Law et al. 2019). Most of the supporting evidence for this theory came from flies (Diptera) (Parkash 2010; Rajpurohit et al. 2016). To summarise, beneficial functions of colours in insects are interrelated with insect biochemical cuticle properties, colour types, life strategies, behaviour, and physiology.

\section{Mechanisms of colour change in insects}

Both the insect colours and the colour change (an ability of an organism to modify its colour in response to specific stimuli) (Umbers et al. 2013; Figon and Casas 2018) can be used to perceive information about an organism itself or about the environment, in which that organism occurs. Some pigments like melanins, pterins, bile pigments, ommochromes are synthesized from precursors. Their effective production needs a proper physiological functioning, and in this way, pigmentbased colouration is consistent with a handicap principle (Zahavi 1975) and conveys information about the quality of an organism (Stoehr 2006). The other pigments, like carotenoids, are acquired by insects from the diet. These pigments contribute more to insect physiology as antioxidants, components of short-range courtship pheromones, or as precursors for visual pigments (Heath et al. 2013). Therefore, they can signal foraging efficiency or anti-oxidative potential of an organism (Møller et al. 2000).

Mechanisms of colour change in insects are closely interconnected with beneficial functions of colours. For example, in the oriental hornet Vespa orientalis (Fig. 4c) yellow purine and pteridine abdominal stripes were shown to absorb solar radiation and convert it into electrochemical energy (Plotkin et al. 2009). This assists better thermoregulation in hornets and better adaptability to environmental conditions. Recently, it was revealed that the proportion of yellow abdominal pigmentation in the common wasp Vespula vulgaris is related to urban heat island effect (Badejo et al. 

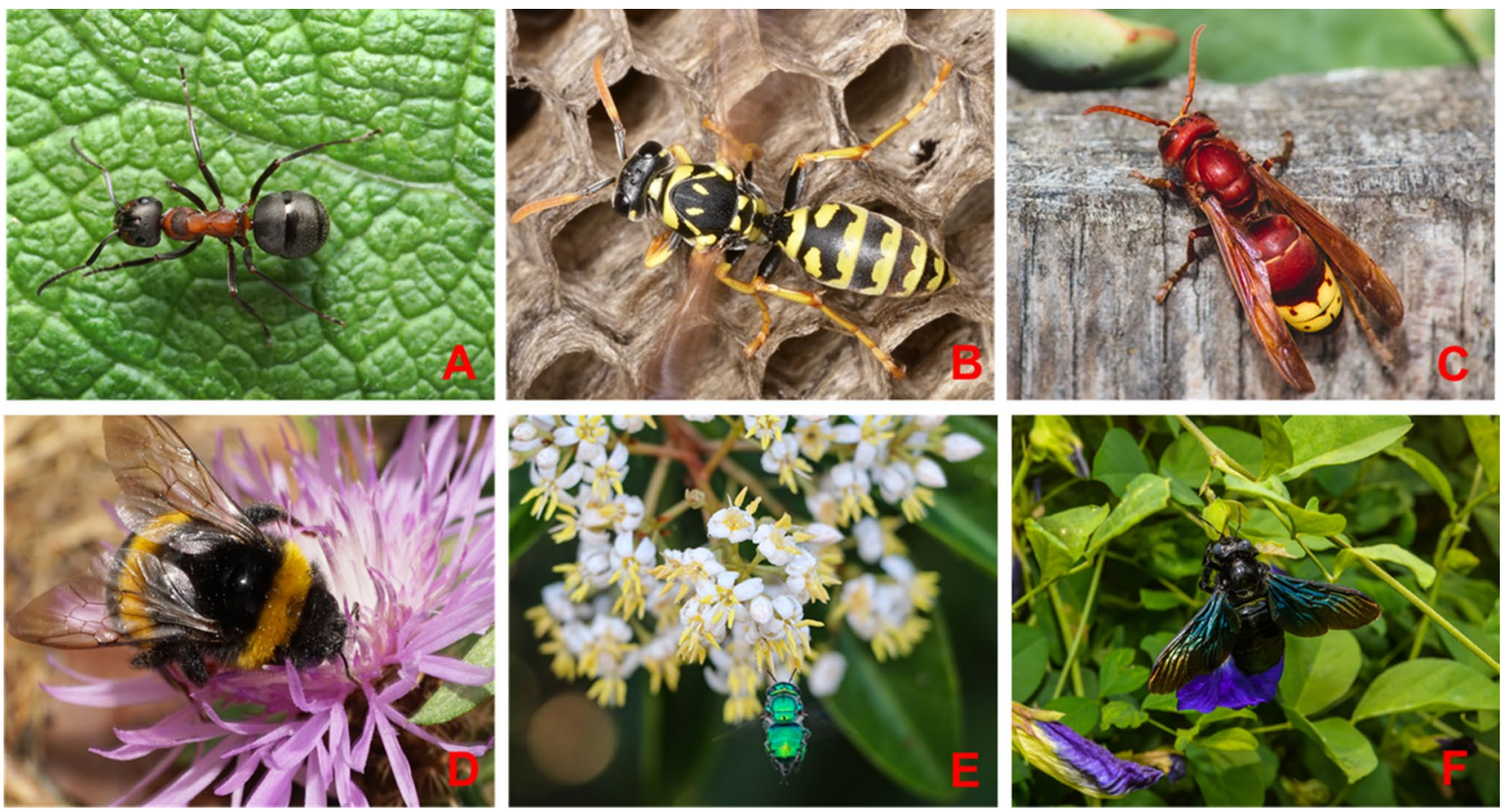

Fig. 4 Examples of various colouration types in different species of hymenopteran insects with different levels of eusociality. a melaninbased pigmental black-and-red colouration of the red wood ant Formica rufa (highly eusocial species); photo $\odot$ Andrey Pavlov. b Melanin and pterin black- and-yellow pigment cuticular colouration of the European paper wasp Polistes dominula (primitively eusocial species); photo (C) Andrey Pavlov. c Melanin-, purine-, pteridine-based pigment colouration the Oriental hornet Vespa orientalis (highly

2020). These findings rise further interest to the discovering mechanisms of colour change in insects.

\section{Social insects: the ecosystem services providers and model organisms for research}

\section{Social insects: definitions of a concept}

Among insects, there is a specific group of organisms"social insects", which are of great ecological importance and represent many interesting examples related to colour functions. Belonging to two taxonomical orders Hymenoptera (ants, wasps, and bees) and Isoptera (termites), social insects comprise a group of insects with specialized castes in their colonies. These castes are based on the division of labour, sharing family members into reproductive individuals and workers, or sometimes soldiers (Brian 1983). Apart from the division of labour, the other two criteria for sociality are cooperative brood care and overlapping generations (Wilson and Hölldobler 2005). Because eusociality has evolved many times independently, hymenopterans retain representatives at different levels of sociality, ranging from eusocial species); photo (C) Tennesssee Witney d Melanin- and pterine-based hair colours in the White-tailed bumblebee Bombus lucorum; photo (C) Sergey. e Structural green colouration in Orchid bee Euglossa dilemma (species, exhibiting eusocial plasticity); photo (C) Laurel A Egan. f Blue pigment and structural cuticular colouration of Carpenter bee Xylocopa sp. (species with signs of week sociality); photo ( ) YuRi Photolife

subsocial, incipiently social, primitively social to advanced eusocial (Rehan and Toth 2015). Species, representing each level of sociality, differ in their major life-history traits, means of communication and the degree of reproductive isolation. Because of such striking differences and due to recent advances in molecular genetics, it has been even suggested for the primitive social insects to substitute the term "cast" into "cooperative breeders" because the females are equipotential (Sumner et al. 2018). The key traits of sociality itself, such as effective population size, level of genetic variation, and invasion success, confer several specific features on their conservation biology (Chapman and Bourke 2008). Despite that eusociality appeared in two major insect groups, it has been also reported for some thrips, beetles, and aphids (Crespi 1992; Kent and Simpson 1992; Stern et al. 1997). As here we are focused on colour benefits for social hymenopterans, we will briefly characterize each of the major groups: ants, wasps, and bees.

\section{Hymenopteran social insects: ants, wasps, bees}

Hymenopteran social insects demonstrate different levels of sociality and provide key ecosystem services, such as 
pollination, biological pest control, organic matter decomposition, and seed-dispersal (Folgarait 1998; Richter 2000; Noriega et al. 2018). Simultaneously they are agricultural pests, invasive alien species, and vectors for pathogen spread (Del Toro et al. 2012; Madden et al. 2017) (Fig. 3).

There are around 16, 000 species of ants (AntWeb 2018) and all of them represent advanced eusociality (Rehan and Toth 2015). For the ecosystems, they are especially important as ecosystem engineers, which alter soil properties, make changes in nutrients and energy fluxes, and modify vegetation (Folgarait 1998; Wills and Landis 2018). They are benefitting natural ecosystems as predators and regulators of food-webs, seed spreaders, and decomposers (Folgarait 1998; Del Toro et al. 2012).

Although there are about 15, 000 aculeate (stinging) wasp species worldwide, only approximately $5 \%$ of those are eusocial and they belong to one family Vespidae (Archer 2012). Eusociality has evolved independently in the subfamilies Stenogastrinae and Polistinae/Vespinae (Hines et al. 2007). Currently, social wasps represent all possible social transitions from primitive to advanced sociality (Rehan and Toth 2015). Social wasps hunt arthropod prey and help in reducing the impact of pest species in farmlands (Gould and Jeanne 1984; Donovan 2003). They can also act as specialized pollinators (Fateryga et al. 2010; Brodmann et al. 2008) and contributors to nutrient flows (Beggs2001). Social wasps are stinging insects and act as pests, as they are causing damage in fruit farms or grape yards (Akre 1978), spreading polymicrobial diseases (Madden et al. 2017).

The total number of bees (Apoidea) in the world is about 20, 000 species (Michener 2000). Around 25\% of this number build up a group of social bees, highly variable in the levels of sociality (Batra 1984). Among bees, tribes Apini (honeybees) and Meliponini (stingless bees) comprised of advanced eusocial species, while tribe Bombini (bumblebees) represent primitively eusocial organisms (Cardinal and Danforth 2011). Honeybees produce honey and are key pollinators of plants in both natural and agricultural landscapes. However, bumblebees and wild bees are no less important, and, in many cases, honeybees cannot substitute them for wildflowers pollination (Goulson 2003). Most of the greenhouse crops, such as tomatoes, depend on bumblebees for pollination (Kevan et al. 1991).

\section{Social insects as model organisms for research}

A long time, social insects have been model organisms to study sociality (Sumner 2006), the evolution of complex mutualism (Gamboa et al. 2003), self-organisation, and aging (Keller and Jemielity 2006). The organised nature of colonies and the limited number of the reproductive caste provided a genetically distinct community that can be properly monitored. The ecological functions of social insects involve interaction with other components of the environment which can provide valuable information in pest management research, pollination ecology, and biomonitoring research.

\section{Diversity of colour functions in social insects}

\section{The effects of social organisation on colour functions}

For the social insects, specific features of sociality such as family complexity and haplodiploidy possess a decisive role for the colour function. For example, in highly eusocial ant and wasp societies, living in underground or inside constructed nests, the role of chemical cues is predominant (Akino 2008). However, recently it was found that in eusocially primitive paper wasp Polistes dominula there was a differential use of visual and chemical cues depending on the colony size (Cini et al. 2019). Therefore, the signalling role of colour may depend on the level of social organisation. Often there are colour differences between sexes in social insects, such as in bumblebees (Pekkarinen 1979) or Polistes wasps (Rusina et al. 2009). Worker ants also demonstrate conspicuous variations in colours (Skaldina and Sorvari 2017b). Interestingly, in worker red wood ants it has been shown that environmental rather than genetic driving forces (Skaldina and Sorvari 2020). That result was opposite to Diacamma ants (Hymenoptera, Ponerinae), in which distinct genetically based colour dimorphism was revealed between male and female genders (Miyazaki et al. 2014). We have summarized several examples of colour functions in social insects (Table 1) and further reviewed the most striking evidence of colour functions in ants, wasps, and bees.

\section{Colours of social insects: camouflage, warning colouration, mimicry}

Ants are probably the major group of social insects which utilise colours for camouflage. Different ant species are uniformly black, brown, or grey coloured, matching tree bark, soil, and rock backgrounds. However, not many studies were concentrated on colour camouflage in ants. To our knowledge, the only exception is research on the ant Basiceros manni, possessing specific structures: "brush" and "holding" hairs. Those structures captured and bonded soil particles and gave greyish tints to originally brown species and therefore benefitted crypsis (Hölldobler and Wilson 1986). There is also evidence for colour camouflage in bees. Thus, in dry grasslands, pale body colouration of bumblebees was suggested to have a cryptic function (Williams 2007).

In many social insects, particularly wasps and bees, but also some ant species, colouration is mainly associated with 
Table 1 Selected examples of colour benefits for the social hymenopterans (ants, bees, wasps)

\begin{tabular}{|c|c|c|c|c|c|}
\hline Group & Species & Benefit & Colour trait & Defined method & Reference \\
\hline \multicolumn{6}{|l|}{ Ants } \\
\hline Ponerinae & Diacamma sp. & $\begin{array}{l}\text { Physical body protection } \\
\text { associated with sexual } \\
\text { colour dimorphism }\end{array}$ & $\begin{array}{l}\text { Indices for cuticular pigmentation: } \\
\text { black in females and yellowish- } \\
\text { brown in males }\end{array}$ & $\begin{array}{l}\text { Digital photographing photo analyses using } \\
\text { adobe Photoshop CS5 }\end{array}$ & (Miyazaki et al. 2014) \\
\hline Formicinae & $\begin{array}{l}\text { Cataglyphis } \\
\text { bombycina }\end{array}$ & Thermoregulation & Silver tins produces by hairs & SEM and TEM imaging & (Willot et al. 2016) \\
\hline Myrmicinae & $\begin{array}{l}\text { Basiceros } \\
\text { manni }\end{array}$ & Camouflage & Structural hairs and soil particles prod & ucing grey tints & $\begin{array}{l}\text { (Hölldobler and Wilson } \\
\text { 1986) }\end{array}$ \\
\hline \multicolumn{6}{|l|}{ Bees } \\
\hline \multirow[t]{2}{*}{$\begin{array}{l}\text { Apidae/ } \\
\text { Meliponini }\end{array}$} & $\begin{array}{l}\text { Melipona cos- } \\
\text { taricensis }\end{array}$ & Thermoregulation & Light vs. dark colour & Visual assessment & $\begin{array}{l}\text { (Perreboom and Bies- } \\
\text { meijer 2003) }\end{array}$ \\
\hline & \multicolumn{5}{|c|}{ Cephalotrigona capitata } \\
\hline \multirow{4}{*}{$\begin{array}{l}\text { Apidae/ } \\
\text { Bombini }\end{array}$} & \multirow[t]{2}{*}{ Bombus spp. } & \multirow[t]{2}{*}{ Thermoregulation } & Light vs. dark colour & Visual assessment & \\
\hline & & & $\begin{array}{l}\text { Seven colour classes and colour- } \\
\text { pattern elements }\end{array}$ & Coding into colour-pattern elements & (Williams 2007) \\
\hline & $\begin{array}{l}\text { Bombus } \\
\text { hortorum }\end{array}$ & Thermoregulation & $\begin{array}{l}\text { Colour forms: light, medium-light } \\
\text { and dark }\end{array}$ & Visual assessment & (Pekkarinen 1979) \\
\hline & $\begin{array}{l}\text { Bombus mel- } \\
\text { anopygus }\end{array}$ & Mimetic diversification & Pigment-based colour & Solubility test and spectrophotometry & (Hines et al. 2017) \\
\hline \multicolumn{6}{|l|}{ Wasps } \\
\hline \multirow[t]{3}{*}{$\begin{array}{l}\text { Vespidae/ } \\
\text { Polistinae }\end{array}$} & $\begin{array}{l}\text { Polistes } \\
\quad \text { dominula }\end{array}$ & Sexual dimorphism & Colour of the face (yellow/black) & Arttificial colour alteration & (Cappa et al. 2016) \\
\hline & $\begin{array}{l}\text { Poliistes } \\
\quad \text { simillimus } \\
\text { Polistes satan }\end{array}$ & $\begin{array}{l}\text { An assessment of rival } \\
\text { quality in males } \\
\text { Signal of relative fertility }\end{array}$ & $\begin{array}{l}\text { Proportion of black pigmentation } \\
\text { on the head and yellow on the } \\
\text { abdomen }\end{array}$ & $\begin{array}{l}\text { Digital photographing photo analyses using } \\
\text { Pro Plus } 5.0\end{array}$ & (de Souza et al. 2014) \\
\hline & $\begin{array}{l}\text { Vespula } \\
\text { vulgaris }\end{array}$ & Thermoregulation & $\begin{array}{l}\text { Areas of brown and black pigmenta- } \\
\text { tion on the head }\end{array}$ & $\begin{array}{l}\text { Digital photographing quantitative measure- } \\
\text { ments }\end{array}$ & $\begin{array}{l}\text { (Tannure-Nascimento } \\
\text { et al. 2008) }\end{array}$ \\
\hline \multirow{2}{*}{$\begin{array}{l}\text { Vespidae/ } \\
\text { Vespinae }\end{array}$} & \multirow[b]{2}{*}{$\begin{array}{l}\text { Vespa orien- } \\
\text { talis }\end{array}$} & \multirow[b]{2}{*}{ Thermoregulation } & \multirow{2}{*}{$\begin{array}{l}\text { Proportion of black pigmentation } \\
\text { Yellow (xanthopterin) }\end{array}$} & Digital photographing quantitative measure- & (Badejo et al. 2018) \\
\hline & & & & $\begin{array}{l}\text { ments } \\
\text { Mass spectrometry }\end{array}$ & (Plotkin et al. 2009) \\
\hline
\end{tabular}

conspicuous outward appearance and poisonous mechanisms of self-defence. For example, the intensity of black-and-yellow colours in Polistes wasps was connected to their toxicity level (Vidal-Cordero et al. 2012). Numerous other chemically nondefended species, like flies, beetles, and spiders, started to mimic social insects in their appearance and behaviour (Brian 1983). This type of mimicry is named Batesian; and mimetic species are highly variable in the degree of their similarity to models (Edmunds 2000). Pérez-Espona et al. (2018) studied Ecitomorpha and Ecitophya beetle species which were protected from predation through mimicry (body shape and colour) to the army ant Eciton burchellii. On the other hand, there are some examples when less chemically defended social insects mimic those which are stronger protected. For example, Australian carpenter ant Camponotus bendigensis, is mimetic to the Jack Jumper bull ant Myrmecia fulvipes, possessing powerful sting and capable for jumping on short distances (Merrill and Elgar 2000). Another Camponotus sp. imitates conspicuous black-and-yellow colouration of poisonous ant Crematogaster inflata (Ito et al. 2004). Besides, social insects exhibit the second type of mimicry. The observed multiple colours of bumblebees have developed into Müllerian mimicry when several chemically well-defended species possess similar phenotypic traits (Stiles 1980; Williams 2007; Hines and Williams 2012).

\section{Colours of social insects: individual quality and mate choice}

Among social insects, signalling function of colour was the most fully studied for the wasps. It was shown that paper wasps Polistes sp. used colours for the assessment of the rival's quality, for the mate choice, or individual recognition (Tibbetts and Dale 2004; Tibbetts 2010; Tibbetts et al. 2014). Prior to engaging in competitive fights and with the aim to protect their nests $P$. gallicus, foundresses assessed social status of their rivals using colour signals (Petrocelli et al. 2015). Highly variable size and shape of clypeal marking in $P$. dominulus were shown to predict dominant status of females (Tibbetts et al. 2011; Tibbetts and Injaian 2014). In P. satan Tannure-Nascimento et al. (2008) showed that female brown facial colour patterns were important for the establishment of linear hierarchy during a nest founding stage. Those facial colour traits were linked to the relative fertility of the foundresses and their capability for successful nest maintenance. Interestingly, in Polistes wasps, it was 
found that females of different colour morphotypes had substantial differences in the mode of nest foundation (Rusina et al. 2007). This might be also related to the role of colour in social interactions among wasps (Tibbetts and Dale 2004; Tibbetts 2006).

Also, social insects use colour for mate choice. It has been shown that in Polistes simillimus, the larger was the proportion of black pigmentation on the head of a male, the higher was the chance of getting a mating partner (de Souza et al. 2014). Male colouration was similarly identified as a mediator of sexual selection in P. dominulus (Izzo and Tibbetts 2012). In this species, yellow abdominal spots in males were proposed to be sexual signals, as females preferred males with smaller and eclipse-shaped yellow spots. In the other species from that genus ( $P$. nimphus and $P$. gallicus) colour traits were linked with reproductive strategies (Rusina et al. 2019). Interestingly, while assessing the fighting ability, $P$. dominula males also used colour patterns (de Souza et al. 2016a). Cappa et al. (2016) showed that individuals of the wasp species $P$. dominula use facial colour markings for sexual interaction and gender identification.

\section{Colours of social insects: thermoregulation, UV-resistance, drought-resistance}

Colouration of social insects is toughly interconnected with their physiology and in some species has proven connections to thermoregulation, humidity-, and UV-light adaptations. Recent findings indicate that the colour lightness (melanisation) of ant assemblages is mainly driven by thermoregulation (Bishop et al. 2016) and UV-resistance (Law et al. 2019). For the Australian ant Iridomyrmex purpureus, a distinct difference in colour forms concerning humidity was established. The "typical" morph preferred wet conditions, while the unusual "blue" morph was more adapted to the dry habitats (Greenslade 1976). In North American ant species Formica neorufibarbis gelida, inhabiting mountain tundra, dark small workers foraged in the morning, when there was a lack of sunlight and heating. While light preferred foraging in the afternoon, when there was an excess of insolation (Bernstein 1976). The thermoregulatory and UV-protective functions of colour was also revealed for the wasps. For example, in Polistes wasps, darker individuals were found to be associated with colder climatic zones (de Souza et al. 2016b). The occurrence of darker individuals in higher latitude was described for the common wasp Vespula vulgaris (Badejo et al. 2018) and social paper wasp Agelaia pallipes (de Souza et al. 2020). In stingless bees, dark coloured individuals warmed up faster than light-coloured ones (Pereboom and Biesmeijer 2003). The authors also linked the distribution of stingless bees with their colouration, as in high latitudes species were completely black, which demonstrated the involvement of colour into thermoregulation.
A similar trend was earlier described in the bumble bees (Pekkarinen 1979). Less information is available for the relationships between colour and immunity, but de Souza et al. (2011) and showed that the melanisation of the Carpenter ant Camponotus fellah increases in response to antibiotic treatment.

\section{The assisting role of social insects' colouration}

\section{The role of colour for species identification}

Various groups of social insects, including bees (Hines and Williams 2012), wasps (Dvořák and Roberts 2006; Dvořák et al. 2012), and ants (Na and Lee 2001) are identified using colour variations on the different body parts. For example, Guerrero and Fernandez (2008) used colour traits for the description of a new species-the ant Forelius damiani in Colombia. Similarly, Sosa-Calvo et al. (2010) used colouration of ant species in Guyana for species identification. Colour of the mandible (whitish), antennae and legs (yellowish), head and gaster (dark-brown or black) as well as waist segments (light brown) were main distinguishing characteristics of Strumigenys royi (Formicidae, Myrmicinae, Attini). On one hand, Dlussky et al. (1998) showed that head colouration can be used for a reliable delimitation of fire ant species. On the other hand, investigation on the colour traits of the Central Asian Lepisiota (=Acantholepis) species allowed combining several previously described species into a polymorphic one-A. semenovi (Dlussky 1981). However, in some cases, species identification using colour patterns was not reliable for distinguishing cryptic species (Carolan et al. 2012; Vesterlund et al. 2014).

\section{The use of colour traits in ecological surveys and biomonitoring}

Various colour traits in different organisms were proposed as effective and non-invasive indicators of environmental stress (Lifshitz and St Clair 2016). Earlier in the current review, we summarised that several colour traits in social insects are sensitive to environmental conditions and reflect the individual performance. Such biological responses are useful for the development of ecological indicators and novel biomarkers in social insects (Skaldina and Sorvari 2017c). For example, we have found that red wood ants Formica lugubris have less melanised heads in environments polluted with heavy metals (Skaldina et al. 2018). Similarly, common wasps Vespula vulgaris possessed decreased areas of melanised facial colour markings in industrial areas, and that decrease was associated with certain metal elements (Skaldina et al. 2020). Colouration of the ant species Formica aquilonia 
was sensitive to forest clear-cutting (Skaldina and Sorvari 2017a). Therefore, with proper further validation colour traits can assist biomonitoring and make some environmental surveys cheaper and more convenient.

\section{The use of colour for research assisting}

Discovering insect colouration has several research-assisting aspects. Those are revealing the range of intra- and withinspecies variability, biochemical properties of pigments and biophysical properties of nanostructures, discovering insects' age or a specific physiological condition, related to colouration.

One of the first studies about wasps' colouration showed diverse within and inter-species variability in North American species of social wasps (Enteman 1904). Since that time, detailed studies on colouration variability in several genera of wasp species such as Vespa (Perrard et al. 2014), Vespula (Clapperton et al. 1989; Badejo et al.2018), Dolichovespula (Eck 1981, 1983) and Polistes (Tibbetts et al. 2011) have been performed. Workers of Formica aquilonia showed colour variation across Fennoscandia and some parts of Russia due to the species' postglacial recolonisation pathways (Gilev et al.2015). Based on the signs of colour, the intraspecific phenotypic differentiation of ants Formica s. str. had been revealed at different scales (Gilev et al. 2006; Antonov and Gilev 2016). Such variations can be used in diverse ecological and evolutional research.

The other research direction is a biochemistry of insect pigments and biophysics of cuticle structure. There are many cases of pigment-based integument or structural colouration in these group of social insects, as ants and wasps' colours are mainly distinguished by pigments (Fig. 4a, b). Pigments, present in hairs, distinguish colouration of numerous bees and bumblebees, like for instance Bombus lucorum (Fig. 4d). However, there is also structural colouration in social insects. For example, metallic-green colouration in primitively eusocial Orchid bee Euglossa dilemma (Fig. 4e) or dark-blue pigment colouration of carpenter bees Xylocopa sp. (mainly solitary insects with signs of primitive eusociality; Fig. 4f). Concerning unusual colouration, Nemésio (2005) for the first time found evidence for fluorescence in Neotropical orchid bee Eulaema niveofasciata, however, the question about its evolutionary meaning remains unclear.

In a stingless bee Melipona quadrifasciata tergite, pigmentation was studied as a marker of hypopharyngeal glands to facilitate certain aged worker capturing (Fagundes et al. 2006). In red wood ants, smaller workers are generally younger and darker than bigger (and older) ones (Gilev 2003; Skaldina and Sorvari 2017b). Therefore, using colour traits as markers of the insect age or status has promising future research avenues.

\section{Future of the social insect colour studies}

\section{Current progress in methods}

Methods to assess insect coloration range from image analysis of standardised pictures of specimens and drawings as well as spectral imaging to utilization of advanced software, which allows processing different channels of information simultaneously (Lehnert et al. 2011). Images can be obtained using a combination of camera and several microscopy methods including stereomicroscopes (Guerrero and Fernández 2008; Sosa-Calvo et al. 2010), scanning electron microscopes (SEM), spectrophotometers (Stelzer et al. 2010) and Raman spectrometry (RS) (Carlo et al. 2017). The useful software for image processing is referred to as both well-known programs such as Photoshop, ImageJ, Pro Plus 5.0 (De Souza et al. 2014; Miyazaki et al. 2014; Skaldina et al. 2017a) and new software specially designed to study colour traits, such as WaspFacer (Skaldina et al. 2020). Furthermore, current computer-assisted image analysis allow utilising readily available images which allows conducting large-scale colour research projects (see e.g., Stelbrink et al. 2019). With the development of photographing techniques, the colour research, based on processing museum collections has received a new rise (de Souza et al. 2016b).

\section{Knowledge gaps and further research directions}

Despite substantial progress, our review revealed several knowledge gaps in the topic. First, very little information is available about evolutionary function of colouration in ants and bees. Second, almost nothing is known about the interrelation between melanisation and pathogen resistance in social insects. Structural and combined types of colouration are much less discovered in comparison to pigment colour type. Finally, the majority of colour studies in social insects are referred to melanin-based colourations, and there is a need to study the other types.

Our renewed scientific interest in insect colouration raises new questions and opens several research topics. In the face of global environmental change (and primarily climate change), the adaptive function of colouration towards thermal conditions and UV-radiation is of special importance. New studies on the relationship between colour and temperature in both model and non-model insects and further practical monitoring actions, based on these studies, will help to preserve biodiversity, and maintain environmental sustainability. Current development of databases and artificial intelligence techniques will create further possibilities for conducting large-scale projects. On the other hand, local scale studies, measuring insect colours and investigating their changes through time will favor our understanding of the ecological process ongoing in certain 
populations. Insect colours should receive greater attention for the development of novel biomonitoring tools and as the research-assisting purposes. The other promising research direction of insect colouration is design of bioinspired biomaterials. The variety of possibilities to develop new functional materials using examples from the insect world is reviewed by Schroeder et al. (2018). Further progress of this research direction might lead to new advances in design and engineering. Further colour research in social insects should consider specific features of sociality.

\section{Conclusions}

The history of colours in the animal kingdom has fascinated biologist early on. Pigment, structural, and combined colour types possess many useful functions. Those are (1) physical and immunological body protection; (2) signalling, including camouflage, unpalatability, rival quality, and mate choice; (3) physiological adaptations to temperature, UVradiation, and desiccation. Available studies allow assuming that among ants, colours are needed principally for camouflage and thermoregulation. In wasps, colour variations have diverse signalling purposes and possess confirmed interrelations with thermoregulation. Climate-related colour variations were also found in bees. However, evolutionary function of colouration in ants and bees remains one of the knowledge gaps. The current rapid development of databases, digital software, and artificial intelligence allows creation the large-scale colour research projects of high ecological importance. Further discovering colouration variability in social insects might favour progress in species identification, biomonitoring, and other research fields such as environmental ecology, biochemistry, biophysics, and biomaterial design.

Acknowledgements We are warmly thankful to Stefan Pinkert and the anonymous reviewer, whose critical comments and suggestions helped to increase the quality of the manuscript. The study was financially supported by Kopion Naturalists' Society (KLYY/Betty Väänänen fund) and Alfred Kordelin Foundation to OB; Jenny and Antti Wihuri Foundation [grants no 00180353 and 00190336] to OS. Photos, used in figures, were purchased according to copyright agreement with Standard license in Shutterstock, all rights reserved.

Author contributions statement $\mathrm{OB}, \mathrm{OS}$ and JS originally formulated the idea of the manuscript, OB and OS wrote the manuscript, AG contributed to writing, JS and AG made an editorial work, OB and OS made table, OS prepared figures.

Funding Open access funding provided by University of Eastern Finland (UEF) including Kuopio University Hospital.

Open Access This article is licensed under a Creative Commons Attribution 4.0 International License, which permits use, sharing, adaptation, distribution and reproduction in any medium or format, as long as you give appropriate credit to the original author(s) and the source, provide a link to the Creative Commons licence, and indicate if changes were made. The images or other third party material in this article are included in the article's Creative Commons licence, unless indicated otherwise in a credit line to the material. If material is not included in the article's Creative Commons licence and your intended use is not permitted by statutory regulation or exceeds the permitted use, you will need to obtain permission directly from the copyright holder. To view a copy of this licence, visit http://creativecommons.org/licenses/by/4.0/.

\section{References}

Abe Y, Nishimura T, Maeto K (2013) Causes of polymorphic melanism and its thermoregulatory function in a parasitoid wasp Meteorus pulchricornis (Hymenoptera: Braconidae). Eur J Entomol 110(4):627-632

Akino T (2008) Chemical strategies to deal with ants: a review of mimicry, camouflage, propaganda, and phytomimesis by ants (Hymenoptera: Formicidae) and other arthropods. Myrmecol News 11:173-181

Akre RD (1978) Biology and pest status of venomous wasps. Ann Rev Entomol 23:215-238

Andersen SO (2010) Insect cuticular sclerotization: a review. Insect Biochem Mol Biol 40(3):166-178

Antonov IA, Gilev AV (2016) Color variability and phenotypic differentiation of the hairy wood ant Formica lugubris Zetterstedt, 1838 (Hymenoptera, Formicidae) in the Baikal Region. Proc Irkutsk Univ. Biol Ecol 15:47-54 (in Russian)

AntWeb 2018. V 7.61.2. www.antweb.org (Accessed on 18.05.2019)

Archer ME (2012) Vespine wasps of the world: behaviour, ecology and taxonomy of the Vespinae. Monograph series, vol 4. Siri Scientific Press, Manchester

Armitage SAO, Siva-Jothy MT (2005) Immune function responds to selection for cuticular colour in Tenebrio molitor. Heredity 94:650-656

Badejo O, Skaldina O, Sorvari J (2018) Spatial and temporal variation in thermal melanism in aposematic common wasp (Vespula vulgaris) in northern Europe. Annal Zool Fenn 55:67-78

Badejo O, Leskinen JTT, Koistinen A, Sorvari J (2020) Urban environment and climate condition-related phenotypic plasticity of the common wasp Vespula vulgaris. Bull Insectol 73:2

Bailey NW (2011) A test of the relationship between cuticular melanism and immune function in wild-caught Mormon crickets. Physiol Entomol 36(2):155-164

Batluzkaya IV (2003) Variability of the melanized pattern of insects under conditions of anthropogenic impact. BelSU Publishing House, Belgorod (in Russian)

Batra SWT (1984) Solitary bees. Sci Am 250(2):120-127

Beggs J (2001) The ecological consequences of social wasps (Vespula spp.) invading an ecosystem that has abundant carbohydrate resource. Biol Conserv 99(1):17-28

Bequaert J (1943) Color variation in the American social wasp Polistes canadansis. Bol Entomol Vanazolana 2:107-124

Bernstein RA (1976) The adaptive value of polymorphism in an alpine ant Formica gellida wheeler. Psyche J Entomol 83(2):180-184

Bishop TR, Robertson MP, Gibb H, van Rensburg BJ, Braschler B, Chown SL, Foord SH, Munyai TC, Okey I, Tshivhandekano PG, Werenkraut V, Parr CL (2016) Ant assemblages have darker and larger members in cold environments. Glob Ecol Biogeogr 25:1489-1499 
Brakefield PM, Wilmer PG (1985) The basis of thermal melanism in the ladybird Adalia bipunctata: differences in reflectance and thermal properties between the morphs. Heredity 54:9-14

Brian MV (1983) Social insects: ecology and behavioural biology. Chapman and Hall, London, p 377

Brodmann J, Twele R, Francke W, Hölzer G, Zhang QH, Ayasse M (2008) Orchids mimic green-leaf volatiles to attract prey-hunting wasps for pollination. Curr Biol 18(10):740-744

Cappa F, Beani L, Cervo R (2016) The importance of being yellow: visual over chemical cues in gender recognition in a social wasp. Beh Ecol 27(4):1182-1189

Cardinal S, Danforth BN (2011) The antiquity and evolutionary history of social behaviour in bees. PLoS ONE 6(6):e21086

Carlo P, Jorge A, Ornosa C (2017) Eumelanin and pheomelanin are predominant pigments in bumblebee (Apidae: Bombus) pubescence. PeerJ 5:e3300

Caro T, Notes A (2005) The adaptive significance of coloration in mammals. Bioscience 55(2):125-136

Caro T, Caswell Stoddard M, Stuart-Fox D (2017) Animal coloration research: why it matters. Phil Transact Royal Soc B 372(1724):20160333

Carolan JC, Murray TE, Fitzpatrick Ú, Crossley J, Schmidt H, Cederberg B, McNally L, Paxton RJ, Williams PH, Brown MJF (2012) Colour patterns do not diagnose species: quantitative evaluation of a DNA barcoded cryptic bumblebee complex. PLoS ONE 7(1):e29251

Chapman RE, Bourke AFG (2008) The influence of sociality on the conservation biology of social insects. Ecol Lett 4(6):650-662

Chapman RE, Simpson SJ, Douglas AE (2013) The insects: structure and function, 5th edn. Cambridge University Press, New York

Cini A, Cappa F, Pepiciello I, Platania L, Dapporto L, Cervo R (2019) Sight in a clique, scent in society: plasticity in the use of nestmate recognition cues along colony development in the social wasp Polistes dominula. Front Ecol Evol 7:444. https://doi. org/10.3389/fevo.2019.00444

Clapperton BK, Lo PL, Moller H, Sandlant GR (1989) Variation in colour markings of German wasps Vespula germanica $(\mathrm{F})$ and common wasps Vespula vulgaris (L) (Hymenoptera: Vespidae) in New Zealand. New Zeal J Zool 16(3):303-313. https://doi. org/10.1080/03014223.1989.10422895

Clusella-Trullas SK, vanWyk JH, Spotila JR (2007) Thermal melanism in ectotherms. J Therm Biol 32:235-245

Cott HB (1940) Adaptive colouration in animals. Oxford University Press, Methuen, $\mathrm{p} 483$

Crespi BJ (1992) Eusociality in Australian gall thrips. Nat Lond 359:724-726

Cuthill IC, Allen WL, Arbuckle K, Caspers B (2017) The biology of color. Science 357:6350 (and 23 Others)

de Souza DJ, Devers S, Lenoir A (2011) Blochmannia endosymbionts and their host, the ant Camponotus fellah: cuticular hydrocarbons and melanisation. Compt Rend Biolog 334:737-741

de Souza AR, Alberto Mourão Júnior CA, Santos do Nascimento FS, Lino-Neto J (2014) Sexy faces in a male paper wasp. PLoS ONE 9(5):e98172

de Souza AR, Lino-Neto J, Tibbetts EA, Turillazzi S, Beani L (2016a) The leks of Polistes dominula paper wasps: tiny abdominal spots play a critical role in male attacks toward potential rivals. Ethol Ecol Evol 29(4):410-419

de Souza AR, Turillazzi S, Lino-Neto J, Santini G (2016b) Colder environment may select for darker paper wasps. Biol J Linn Soc 120(3):700-704

de Souza AR, Mayoriquin A, Sarmiento CE (2020) Paper wasps are darker at high elevation. J Therm Biol 89:102535

Del Toro I, Ribbons RR, Pelini SL (2012) The little things run the world revisited: a review of ant-mediated ecosystem services and disservices (Hymenoptera: Formicidae). Myrmecol News $17: 133-146$

Dlussky GM (1981) Ants of deserts. Nauka, Moscow

Dlussky GM, Fedoseeva EB, Thompson LCh (1998) Variability of the ants Solenopsis richteri and S. wagneri (Hymenoptera, Formicidae): statistical analyses of morphometric characters. Biol Bull Rev 118(3):283-298

Donovan B (2003) Potential manageable exploitation of social wasps, Vespula spp. (Hymenoptera, Vespidae) as generalist predators of insect pests. Internat J Pest Manag 49(4):281-285

Dubovskiy IM, Whitten MM, Kryukov VY, Yaroslavtseva ON, Grizanova EV, Greig C, Mukherjee K, Vilcinskas A, Mitkovets PV, Glupov VV, Butt TM (2013) More than a colour change: insect melanism, disease resistance and fecundity. Proc Royal Soc B 280:20130584

Dvořák L, Roberts PM (2006) Key to the paper and social wasps of central Europe (Hymenoptera: Vespidae). ACTA Entomol Mus Nat Pragae 46:221-244

Dvořák L, Ghahari H, Carpenter JM, Abbasi R (2012) On the distribution and taxonomy of vespine wasps of Iran (Hymenoptera: Vespidae: Vespinae). ACTA Mus Morav Sci Biol 97(2):69-86

Eck R (1981) Zur verbreitung und variabilitat von Dolichovespula norvegica (Hymenoptera, Vespidae). Entomol Abhandl B 44(7):133-152 (in German)

Eck R (1983) Zur verbreitung und variabilitat von Dolichovespula saxonica (Hymenoptera, Vespidae). Entomole Abhandl1B 46(8):151-176

Edmunds M (2000) Why are there good and poor mimics? Biol J Linn Soc 70:459-466

Endler JA, Mappes J (2017) The current and future state of animal colouration research. Phil Transact Royal Soc B 372:2016352

Enteman W (1904) Colouration in Polistes. Carnegie Institution of Washington, Washington, $\mathrm{p} 88$

Evison SEF, Gallagher HD, Thompson JJw, Siva-Jothy MT, Armitage SAO (2017) Cuticular colour reflects underlying architecture and is affected by a limiting resource. J Insect Physiol 98:7-13

Fagundes IB, Campos L, Eduardo Serrão J (2006) Tergite pigmentation indicates hypopharyngeal gland developmental degree in Melipona quadrifasciata (Hymenoptera, Apidae, Meliponini). Sociobiology 48(1):51-62

Fateryga AV (2010) Trophic relations between vespid wasps (Hymenoptera, Vespidae) and flowering plants in the Crimea. Entomol Rev 90(6):698-705

Fedorka KM, Lee V, Winterhalter WE (2013) Thermal environment shapes cuticle melanism and melanin-based immunity in the ground cricket Allonemobius socius. Evol Ecol 27:521-531

Figon F, Casas J (2018) Morphological and physiological colour changes in the animal kingdom. In: eLS. Wiley, Chichester. https://doi.org/10.1002/9780470015902.a002806

Fitzstephens DM, Getty T (2000) Colour, fat and social status in male damselflies Calopteryx maculata. Anim Behav 60(6):851-855

Folgarait PJ (1998) Ant biodiversity and its relationship to ecosystem functioning: a review. Biodiv Conserv 7:1221-1244

Fuzeau-Braesch S (1972) Pigments and colour changes. Annu Rev Entomol 17:403-424

Gamboa GJ, Reeve HK, Pfennig DW (2003) The evolution and ontogeny of nestmate recognition in social wasps. Annu Rev Entomol 31(1):431-454

Gilev AV (2003) Population structure of Formica aquilonia (Hymenoptera, Formicidae) in the Middle Ural. Biol Bull 123(3):223-228

Gilev AV, Rusina LYu, Glotov SV, Skorokhod OV, Firman LA (2006) Color variability of Formica pratensis Retz. (Hymenoptera: Formicidae) in forest and forest-steppe biocenoses in Southern and Eastern Ukraine and Middle Ural. Charkiv Entomol Gazette 14(1-2):103-109 
Gilev AV, Mershchiev AV, Malyshev DS (2015) Interpretation of postglacial recolonization of Formica aquilonia (Hymenoptera, Formicidae) in Fennoscandia according to workers' color variation. Entomol Rev 95(8):941-946

Gillespie JP, Kanost MR (1997) Biological mediators of insect immunity. Annu Rev Entomol 42:611-643

Gould WP, Jeanne RL (1984) Polistes wasps (Hymenoptera: Vespidae) as control agents for Lepidopterous cabbage pests. Environ Entomol 1(1):150-156

Goulson D (2003) Conserving wild bees for crop pollination. Food Agric Environ 1(1):142-144

Greenslade PJM (1976) The meat ant Irydomyrmex purpureus (Hymenoptera: Formicidae) as a dominant member of ant communities. J Aust Ent Soc 15:237-240

Guerrero RJ, Fernandez F (2008) A new species of the ant genus Forelius (Formicidae: Dolichoderinae) from the dry forest of Colombia. Zootaxa 1958:51-60

Heath JJ, Cipollini DF, Stireman JO III (2013) The role of carotenoids and their derivatives in mediating interactions between insects and their environment. Arthropod-Plant Inte 7(1):1-20

Hines HM, Williams PH (2012) Mimetic colour pattern evolution in the highly polymorphic Bombus trifasciatus (Hymenoptera: Apidae) species complex and its comimics. Zool J Linn Soc 166:805-826

Hines HM, Hunt JH, O'Connor TK, Gillespie JJ, Cameron SA (2007) Multigene phylogeny reveals eusociality evolved twice in vespid wasps. PNAS 104(9):3295-3299

Hines HM, Witkowski P, Wilson JS, Wakamatsu K (2017) Melanic variation underlies aposematic color variation in two hymenopteran mimicry systems. PLoS ONE 12(7):e0182135

Hölldobler B, Wilson EO (1986) Soil-binding pilosity and camouflage in ants of the tribes Basicerotini and Stegomyrmecini (Hymenoptera, Formicidae). Zoomorphology 106(1):12-20

Ito F, Hashim R, Huei YS, Kaufmann E, Akino T, Billen J (2004) Spectacular Batesian mimicry in ants. Naturwissenschaften 91:481-484

Izzo AS, Tibbetts EA (2012) Spotting the top male: sexually selected signals in male Polistes dominulus wasps. Anim Bahav 83:839-845

Kangassalo K, Kosonen K, Pölkki M, Sorvari J, Krams I, Rantala MJ (2016) Immune challenge has a negative effect on cuticular darkness in the mealworm beetle, Tenebrio molitor. Annal Zool Fenn $53: 255-262$

Keller L, Jemielity S (2006) Social insects as a model to study the molecular basis of ageing. Experimen Gerontol 41(6):553-556

Kemp DJ, Rutowski RL (2011) The role of coloration in mate choice and sexual interactions in butterflies. Adv Study Behav 43:55-92

Kent DS, Simpson JA (1992) Eusociality in the beetle Austroplatypus incompertus. Naturwissenschaften 79(2):86-87

Kevan PG, Straver WA, Offer M, Laverty TM (1991) Pollination of greenhouse tomatoes by bumblebees in Ontario. Proc Entomol Soc Ontario 122:15-19

Korsun OV (2000) Phenotypic variations of Adalia bipunctata natural populations (Coleoptera, Coccinelidae) in East Transbaikalia. Sib Ecol J 6:723-726

Kreslavskiy AG (1975) Hereditary polymorphism, hereditary monomorphism and their role in the evolution of color in leaf beetles (Coleoptera, Chrysomelidae). Biol Bul 36(6):878-886

Law SJ, Bishop TR, Eggleton P, Griffiths H, Ashton L, Parr C (2019) Darker ants dominate the canopy: testing macroecological hypotheses for patterns in colour along a microclimatic gradient. J Anim Ecol: https://doi.org/10.1111/1365-2656.13110

Lehnert MS, Balaban MO, Emmel TC (2011) A new method for quantifying color of insects. Florid Entomol 94(2):201-207
Lifshitz N, St Clair CC (2016) Coloured ornamental traits could be effective and non-invasive indicators of pollution exposure for wildlife. Conserv Physiol 4:1-16

Lindstedt C, Morehouse N, Pakkanen H, Casas J, Christides J-P, Keimppainen K, Lindtröm L, Mappes J (2010) Characterizing the pigment composition of a variable warning signal of Parasemia plantaginis larvae. Funct Ecol 24:759-766

Lindström L, Alatalo RV, Lyytinen A, Mappes J (2004) The effect of alternative prey on the dynamics of Batesian and Mullerian mimicry. Evolution 58:1294-1302

Madden AA, Boyden SD, Soriano J-AN, Corey TB, Jonathan WL, Fierer N, Starks PT (2017) The emerging contribution of social wasps to grape rot disease ecology. PeerJ 5:e3223

Merrill DN, Elgar MA (2000) Red legs and golden gasters: Bayesian mimicry in Australian ants. Naturwissenschaften 87:212-215

Michener CD (2000) The bees of the world. The Johns Hopkins University Press, Baltimore and London, p 913

Miyazaki S, Okada Y, Miyakawa H, Tokuda G, Cornette R, Kishikawa S, Maekawa K, Miura T (2014) Sexually dimorphic body colour is regulated by sex-specific expression of yellow gene in Ponerine ant Diacamma sp. PLoS ONE 9(3):e92875

Møller AP, Biard C, Blount JD, Houston DC, Ninni P, Saino N (2000) Carotenoid-dependent signals: indicators of foraging efficiency, immunocompetence or detoxification ability? Av Poult Biol Revi 11(3):137-159

Na JPS, Lee CY (2001) Identification key to common urban pest ants in Malaysia. Tropic Biomed 18:1-17

Nemésio A (2005) Fluorescent colours in orchid bees (Hymenoptera: Apidae). Syst Morphol Physiol 34(6):933-936

Noriega JA, Hortal J, Azcárate FM et al (2018) Research trends in ecosystem services provided by insects. Basic Appl Ecol 26:8-23

Pekkarinen A (1979) Morphometric colour and enzyme variation in bumblebees (Hymenoptera, Apidae, Bombus) in Fennoscandia and Denmark. Acta Zool Fenn 158:60

Pereboom JJM, Biesmeijer JC (2003) Thermal constraints for stingless bee foragers: the importance of body size and colouration. Oecologia 137(1):42-50

Pérez-Espona S, Goodall-Copestake WP, Berghoff SM, Edwards KJ, Franks NR (2018) Army imposters: diversification of army ant-mimicking beetles with their Eciton hosts. Insect Soc 65(1):59-75

Pérez-Rodríguez L, Jovani R, Stevens M (2017) Shape matters: animal colour patterns as signals of individual quality. Proc Royal Soc B 284(1849):2016-2446

Perrard A, Arca M, Rome Q, Muller F, Tan J, Bista S et al (2014) Geographic variation of melanisation pattern in a hornet species: genetic differences, climatic pressures of aposematic constraints? PLoS ONE 9(4):e94162

Petrocelli I, Ricciardi G, de Souza AR, Ninu A, Turillazzi S (2015) Visual signals of individual quality in a European solitary founding paper wasp. Ethology 121:300-307

Pinkert S, Zeuss D (2018) Thermal biology: melanin-based energy harvesting across the tree of life. Curr Biol 16(20):R887-889

Pinkert S, Brandl R, Zeuss D (2016) Colour lightness of dragonfly assemblages across North America and Europe. Ecography 40(9):1110-1117

Plotkin M, Volynchik S, Ermakov NY, Benyamini A, Boiko Y, Bergman DJ, Ishay JS (2009) Xanthopterin in the oriental hornet (Vespa orientalis): light absorbance is increased with maturation of yellow pigment granules. Photochem Photobiol 85(4):955-961

Prisniy AV (1980) Morphological base of pronotum pattern in Colorado potato beetle (Leptinotarsa decemlineata). Zool J 59(10):1575-1577 (in Russian) 
Rajpurohit S, Parkash R, Ramniwas S (2008) Body melanisation and its adaptive role in the thermoregulation and tolerance against desiccating conditions in drosophilids. Entomol Res 38:49-60

Rehan SM, Toth AL (2015) Climbing the social ladder: the molecular evolution of sociality. Trends Ecol Evol 30(7):426-433

Richter MR (2000) Social wasp (Hymenoptera: Vespidae) foraging behaviour. Annu Rev Entomol 45:121-150

Roulin A (2014) Melanin-based colour polymorphism responding to climate change. Global Change Biol 20:3344-3350

Rusina LYu, Rusin IYu, Starr SK, Fateryga AB, La F (2007) Modes of colony foundation by females of different morphotypes in the paper wasps (Hymenoptera, Vespidae, Polistes Latr.). Entomol Rew 87(9):1155-1173

Rusina LYu, Firman LA, Privalova EA (2009) Reproductive strategies of male paper wasps (Hymenoptera, Vespidae) in the southern Dnieper area. Entomol Rev 89(8):881-890

Schroeder TBH, Houghtaling J, Wilts BD, Mayer M (2018) It's not a bug, it's a feature: functional materials in insects. Adv Mater 30(19): 1705322

Schweiger AH, Beierkuhlein C (2015) Size dependency in colour patterns of Western Palearctic carabids. Ecography 39(9):846-857

Shamim G, Ranjan SK, Pandey DM, Ramani R (2014) Biochemistry and biosynthesis of insect pigments. Eur J Entomol 111(2):149-164

Shvanvich BN (1949) General entomology course. Sov Sci, Moscow (in Russian)

Skaldina O, Sorvari J (2017a) Wood ant colouration as an ecological indicator for the level of disturbance in managed coniferous forests. Ecol Indic 72:444-451

Skaldina O, Sorvari J (2017b) Not simply red: colouration of red wood ant Formica rufa (Hymenoptera: Formicidae) is polymorphic, modular and size-dependent. Eur J Entomol 114:317-324

Skaldina O, Sorvari J (2017c) Biomarkers of ecotoxicological effects in social insects: In: Kesari KK (ed) Perspectives in environmental toxicology. Elsevier, pp 203-214

Skaldina O, Sorvari J (2020) Phenotypic diversity in red wood ants: is kinship involved? Eur J Entomol 117:27-33

Skaldina O, Peräniemi S, Sorvari J (2018) Ants and their nests as indicators for industrial heavy metal contamination. Environ Pollut 240:574-581

Skaldina O, Cizek R, Peräniemi S, Kolehmainen M, Sorvari J (2020) Facing the threat: common yellowjacket wasps as indicators of heavy metal pollution. Environ Sci Poll Res. https://doi. org/10.1007/s11356-020-09107-2

Sosa-Calvo J, Schultz TR, LaPolla JS (2010) A review of the dacetine ants of Guyana (Formicidae: Myrmicinae). J Hymenopt Res 19(1):12-43

Stavenga DG, Leertouwer HL, Wilts BD (2014) The colouration toolkit of the Pipevine Swallowtail butterfly, Battus philenor: thin films, papiliochromes, and melanin. J Comparat Physiol A 200:547-561

Stelbrink P, Pinkert S, Brunzel S, Kerr J, Wheat CW, Brandl R, Zeuss D (2019) Colour lightness of butterfly assemblages across North America and Europe. Sci Rep 9:1760

Stern DL, Whitfield JA, Foster WA (1997) Behavior and morphology of monomorphic soldiers from the aphid genus Pseudoregma (Cerataphidini, Hormaphididae): implications for the evolution of morphological castes in social aphids. Insect Soc 44:379-392

Stevens M, Marilaita S (2009) Animal camouflage: current issues and new perspectives. Philosoph Transact Royal Soc B 364:423-427

Stiles EW (1980) The evolutionary significance of bumble bee characteristics in male bumblebees: automimicry vs. thermoregulation. Evolution 33(3):941-957
Stoehr AM (2006) Costly melanin ornaments: the importance of taxon? Funct Ecol 20:276-281

Sumner S (2006) Determining the molecular basis of sociality in insects. progress, prospects and potential in sociogenomics. Annal Zool Fenn 43:423-442

Sumner S, Bell E, Taylor D (2018) A molecular concept of cast in insect societies. Curr Opi Insect Sci 25:42-50

Tannure-Nascimento IC, Nascimento FS, Zucchi R (2008) The look of royalty: visual and odour signal of reproductive status in a paper wasp. Proc Royal Soc B 275:2555-2561

Théry M, Gomez D (2010) Chapter 7. Insect colours and visual appearance in the eyes of their predators. Advan Insect Physiol 38:267-353

Tibbetts EA (2006) Badges of status in worker and gyne Polistes dominulus wasps. Annal Zool Fenn 43(5):575-582

Tibbetts EA (2010) The condition dependence and heritability of signalling and nonsignaling color traits in paper wasps. Am Nat 175(5):495-503

Tibbetts EA, Dale J (2004) A socially enforced signal of quality in a paper wasp. Lett Nat 432:218-222

Tibbetts EA, Injaian A (2014) Cognition across castes: individual recognition in worker Polistes fuscatus wasps. Anim Behav 87:91-96

Tibbetts EA, Sheehan MJ, Jinn J (2014) Coevolution of visual signals and eye morphology in Polistes paper wasps. Biol Lett 10:20140254

True JR (2003) Insect melanism: the molecules matter. Trends Ecol Evol 18(12):640-647

Umbers KDL (2013) On the perception, production and function of blue colouration in animals. J Zool 289(4):229-242

van Gossum H, Stoks R, De Bruyn L (2001) Reversible frequency: dependent switches in male mate choice. Proc Royal Soc B 268(1462):83-85

Vesterlund S-R, Kakko M, Vasemägi A, Sorvari J (2014) Status and monitoring of the buff-tailed bumblebee Bombus terrestris Linnaeus (Hymenoptera: Apidae) in Southern Finland. Entomol Fenn 25:49-56

Vidal-Cordero JM, Moreno-Rueda G, Lopez-Orta A, Marfil-Daza C, Ros-Santaella JL, Ortiz-Sánchez FJ (2012) Brighter-colored paper wasps (Polistes dominula) have larger poison glands. Front Zool 9:20

Viviani VR (2002) The origin, diversity, and structure function relationship of insect luciferases. Cell Mol Life Sci 59(11):1833-1850

Vukusic P, Sambles JP (2003) Photonic structures in biology. Nature 424:852-855

Williams P (2007) The distribution of bumblebee colour pattern worldwide: possible significance for thermoregulation, crypsis and warning mimicry. Biol J Linn Soc 92:97-118

Willot Q, Simonis P, Vigneron J-P, Aron S (2016) Total internal reflection accounts for the bright color of the Saharan silver ant. PLoS ONE 11(4): 0152325

Wills BD, Landis DA (2018) The role of ants in northern temperate grasslands: a review. Oecologia 186(2):323-338

Wilson EO, Hölldobler B (2005) Eusociality: origin and consequences. Proc Nat Academy Sci 102(38):13367-13371

Zahavi A (1975) Mate selection: a selection for a handicap. J Theor Biol 53(1):205-214

Zeuss D, Brandl R, Brändle M, Rahbek C, Brunzel S (2014) Global warming favours light-coloured insects in Europe. Nat Commun $5: 3874$ 


\section{Affiliations}

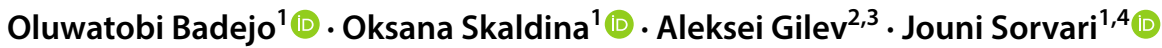

Oluwatobi Badejo

oluwatobi.badejo@uef.fi

Aleksei Gilev

gilev123@yandex.ru

Jouni Sorvari

jouni.sorvari@utu.fi

1 Department of Environmental and Biological Sciences, University of Eastern Finland, Yliopistonranta 1, P.O.

Box 1627, 70211 Kuopio, Finland
2 Institute of Plant and Animal Ecology (IPAE), Ural Centre of the Russian Academy of Sciences, 8 Marta Street, 202, 620144 Yekaterinburg, Russia

3 Institute of Plant and Animal Ecology, Ural Branch, Russian Academy of Sciences, Ural Federal University, Mira Street, 19, 620002 Ekaterinburg, Russia

4 Department of Biology, University of Turku, 20014 Turku, Finland 